\title{
熱感知器の作動時間予測のための計算手法 A CALCULATION METHOD FOR PREDICTING HEAT DETECTOR'S RESPONSE
}

\author{
山内幸雄*，万本＼cjkstart敦**，森田昌宏*** \\ Yukio YAMAUCHI, Atsushi MAMMOTO and Masahiro MORITA
}

\begin{abstract}
Utilizing a zone model and a ceiling-jet model, a simple calculation method for predicting heat detector's response is presented. The parameters are the floor area and the ceiling height of the room, the radial distance of the detector from the fire axes, time history of the heat release rate of the fire, and the response characteristics of the detector. Application of the RTI-C model is discussed and a method utilizing two RTI's, one for the sensor element and the other for the detector body, is introduced. The method using two RTI's shows better results than the original RTI-C model, which is derived for predicting the response of sprinkler heads. In addition, a calculation method for predicting the response of rate-of-rise heat detector is presented. Overall performance of the prediction method is tested with experiments..
\end{abstract}

Keywords: Fire detector, Thermo-detector, Response, Fire Plume, Convective heat transfer, Conduction of heat 火災感知器, 熱感知器, 応答, 火災気流, 対流熱伝達, 熱伝導

\section{1. はじめに}

建物内に設置されている火災感知器（Fire detector）の作動は, 初期消火や避難などの対応行動や，消火設備や防排煙設備などの 安全設備の制御の起点となる重要な事象である. 建物の設計時, 想定される火源に対して，火災感知器がどの時点で作動するかが 的確に予測できれば，より具体的に安全システムの検討が可能と なる. 本研究の目的は，建物の火災安全性を評価する際に想定さ れる火源に対し, 建物内に設置された火炎感知器がどの時点で作 動するかを予測するための簡便なツールを提供することである.

火災感知器の種類としては, 熱 (温度変化) を利用して火災を 検出する熱感知器と燃焼時に発生する煙を利用して火災を感知す る煙感知器の二つが一般的に多く使われている. 本報では, 熱感 知器の作動時間を予測するための計算手法について報告する.

\section{1 具体的な課題}

室内に設置された火災感知器の作動時間を予測するという課 題は，与えられた火源に対して天井に設置された感知器の周囲環 境がどのように変化するかという問題と, 環境条件の変化に対し て感知器がどのように応答するかという問題の二つに分けて考え ることができる. 室内の任意の場所で，特定の可燃物が，ある時 間的な発熱速度パターンで然焼し, 熱と煙を放出したとき, 設置 された感知器がどの時点で作動し，そのときに火源や室内の状態
がどのようになっているかを予測することが，具体的な課題であ る.

熱感知器には，感知部の温度が一定值を超えたときに作動する 定温式感知器と, 温度上昇率が一定值を超えたときに作動する差 動式感知器の二種類がある，そのそれぞれを対象として作動時間 を予測するための計算手法を検討する. ただし，感知部が線状の 分布型感知器は対象外とし, 点状の感知部を持つスポット型熱感 知器だけを考える.

\section{2 計算手法の概要}

対象とする空間は壁により閉じられているか，または梁等によ り部分的に閉じられているものとする. また，天井面は少なくと も火源直上から感知器までの間は水平であると仮定する. 基本的 なパラメータは, 部屋の床面積 $(S)$, 火源から天井までの高さ $(H)$, 火源軸から感知器までの水平距離 $(r)$ および感知器の応答特性で ある (Fig. 1). 壁, 天井, 床等の構造体は燃焼しないものとし, 室内に置かれた屑箱，家具等，単体の可然物が燃焼することを考 える. 燃焼物の発熱速度の時閒変化のデータは入力条件として与 えるものとする.

\footnotetext{
* ホーチキ㑣開発研究所 主席研究具・理修 (東京理科大学大学院理工学研究科博士課程 建築学専攻在籍)

** ホーチキ(侏開発研究所

*** 東京理科大学理学部数理情報科学科 教授・理博
}

Senior Scientist, Research and Development Lab., Hochiki Corp., M. Sc.

Also a Student in Dept. of Architecture, Graduate School, Faculty of Science and Technology, Tokyo Univ. of Science

Managing Scientist, Research and Development Lab., Hochiki Corp., B. Sc.

Prof., Dept. of Applied Mathematics, Faculty of Science, Tokyo Univ. of Science, Ph. D. 
Radial distance: $\mathbf{r}$

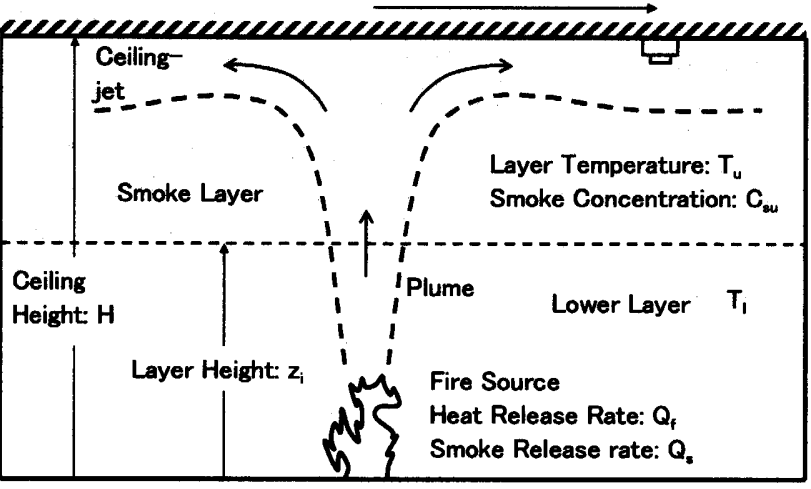

Fig. 1 Fire detector in a room fire environment

計算手順は以下のとおりである.

(1) ゾーンモデルによる煙層高さおよび煙層平均温度の計算 使用する計算モデルは, 時間の関数として与えられた火源発熱速 度に対して, 煙層高さと煙層内の平均温度の時間変化が精度よく 予測できるものであることが条件となる. 少なくとも壁や天井へ の対流熱伝達のモデルが含まれていないと，この条件は満足され ない. 火災感知器の作動に関わる初期の火災における温度上昇は 小さいので, 輻射による熱伝達の要素が含まれていることは必須 ではない.ただし，火源発熱速度 $Q_{j}$ の一部が輻射により火炎から 直接失われ，対流に寄与しないことに対する考慮は必要である.

(2) 二層環境における等価発熱速度および等価天井高さの計算

以下の関係式を使って, 煙層中のプルームの流れを近似する等 価発熱速度 $Q_{p e}$ および等価天井高さ $H_{e}$ を求める. 式の導出方法に ついは第 2 節で詳しく述べる.

$Q_{p e}=Q_{p}-W_{p} \cdot \rho_{0} C_{p}\left(T_{u}-T_{0}\right)$

$H_{e}=H+\left[\left(Q_{p} / Q_{p e}\right)^{1 / 5}-1\right] \cdot z_{i}$

(3) 二層環境における天井流中の温度および流速の計算

等価発熱速度 $Q_{p e}$ および等価天井高さ $H_{e}$, 水平距離 $r$ を Alpert ${ }^{1)}$, Heskestad and Delichatsios ${ }^{2}$ 等の天井流 (Ceiling-jet) の関係式に代 入し, 感知器付近の流速および上昇温度を求める. 本報では Heskestad and Delichatsios ${ }^{2}$ の関係式を使った結果を示す.

(4) 感知器出力の計算

(3)で求めた感知器周辺の環境条件を感知器応答の予測モデル に入力し, 感知器出力の予測值を求める. 本報では, Heskestad and $\mathrm{Bill}^{3)}$ の RTI-C モデルを改良した方法により感知部の温度を計算 し, さらに新たに開発した計算手法により差動式熱感知器の出力 を求める. 具体的な計算方法については，第 3 節で詳しく説明す る.

\section{(5) 作動条件との比較}

(4)で得られた感知器出力を作動条件と比較する. 出力値が作動 条件を満たした時間が作動時間である. 作動条件の詳細について も第 3節で述べる.

\section{2. 天井付近における感知器周囲環境の予測}

\section{1 ゾーンモデルによる煙層の予測}

ゾーンモデルは, 煙流動予測のための工学的ツールとしては既 に完成されたものと考えてよく，BRI2002 コード4)，CFAST コー ド 5)等を用いて, 初期火炎時に形成される二層環境を精度よく予 測することができる. 本研究では, 以下の要素からなる単室モデ ルを作成し, 検証に用いた（Fig. 2). ゾーンモデルについては他 の文献 4).55,6)で詳しく説明されているので, ここでは計算式を列举 するにとどめる. なお, 本報で使われている変数表記の説明を最 後にまとめて示した.

(1) 質量保存

$\rho_{0} S \frac{\mathrm{d} z_{i}}{\mathrm{~d} t}=m_{l}-m_{p}$
$S \frac{\mathrm{d}}{\mathrm{d} t}\left[\rho_{u}\left(H-z_{i}\right)\right]=m_{p}-m_{u}$

(2) エネルギー保存

$\frac{\mathrm{d} P}{\mathrm{~d} t}=\frac{R}{C_{V} S H}\left(Q_{p}-q_{c}+q_{l}-q_{u}\right)=0$

ここに,

$Q_{p}=Q_{f}-Q_{R}$

$Q_{c}=h\left(T_{u}-T_{w}\right) A$

$q_{l}=m_{l} C_{P} T_{0}, \quad q_{u}=m_{u} C_{P} T_{u}$

(3) 状態方程式

$P=\rho \cdot R \cdot T$

(4) 壁内の熱伝導（一次元）

$\frac{\partial T}{\partial t}=a \frac{\partial^{2} T}{\partial x^{2}}$

境界条件：

$-\left.\lambda_{c} \frac{\partial T}{\partial x}\right|_{x=0}=h\left(T_{u}-T_{w}\right),-\left.\lambda_{c} \frac{\partial T}{\partial x}\right|_{x=l}=0$

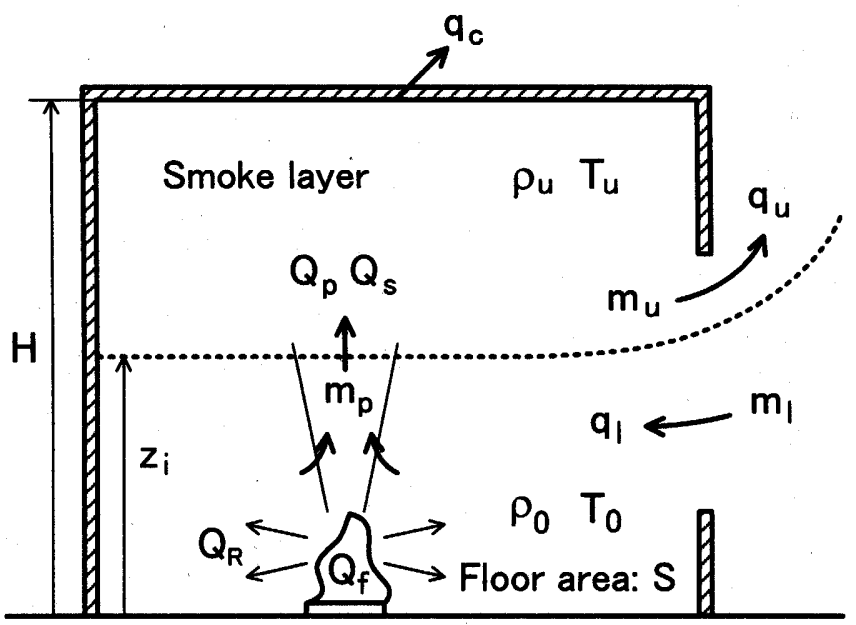

Fig. 2 A schematic of zone model 


\section{2 二笮環境中におけるプルームの挙動}

Morton, Taylor and Turner ${ }^{7}$ は，鉛直方向に密度分布のある（水平 方向には一様の）層をなす環境において点源から発生したプルー ムの挙動を解析するための理論式を提供している. その方程式の 一様な環境に対する解は，火災研究者の間でよく知られている. 同じ論文で, 鈆直方向に密度分布がある場合について詳しい解析 がなされている. Morton, Taylor and Turner ${ }^{7} か ゙$ 示した方程式は一般 性を保つために密度変化により記述されているが, 空気が理想気 体であると仮定すれば，以下のような温度変化の式に書き換える ことができる.

プルーム中の鉛直方向の流速 $(u)$ および上昇温度 $(\Delta T)$ の水 平分布は軸対称で以下のようなガウス分布になっていると仮定す る.

$u=u_{m} \exp \left(-r^{2} / b^{2}\right)$

$\Delta T=\Delta T_{m} \exp \left(-r^{2} /(\lambda b)^{2}\right)$

さらに流れが定常であると仮定すると，鉛直方向に温度分布があ る環境において, プルームにより上方 ( $\mathrm{z}$ 方向) に運ばれる質量, 運動量およびエネルギ一流束の保存則は以下のように書き表すこ とができる.

$\frac{\mathrm{d}}{\mathrm{d} z}\left(\pi \cdot b^{2} u_{m}\right)=2 \pi \cdot b \alpha \cdot u_{m}$

$\frac{\mathrm{d}}{\mathrm{d} z}\left(\frac{1}{2} \pi \cdot b^{2} u_{m}^{2}\right)=\pi \cdot \lambda^{2} b^{2} g \frac{\Delta T_{m}}{T_{0}}$

$\frac{\mathrm{d}}{\mathrm{d} z}\left(\frac{1}{\left(1+1 / \lambda^{2}\right)} \pi \cdot b^{2} u_{m} \rho_{0} C_{P} \Delta T_{m}\right)=-\pi \cdot b^{2} u_{m} \rho_{0} C_{P} \frac{\mathrm{d} T_{a}}{\mathrm{~d} z}$

式(14)〜(16)において, プルーム中の温度変化の最高值は基準温度

$\left(T_{0}\right)$ に比べて十分小さい (Boussinesq 近似が適用可能である)

と仮定されている. また, プルームの周囲温度 $\left(T_{a}\right)$ は水平方向 には一様であるが, 高さ $z$ により変化すると仮定されている.

式(14)と(15)は, 一様な環境中のプルームの方程式と同一である. 式(16)は, 周井温度 $\left(T_{a}\right)$ が上方に行くにしたがって高くなる（温 度勾配が正の）場合, プルームのエネルギー流束が上方に行くに したがって見かけ上減少することを示す。ここでいうエネルギー 流束とは, 温度 $T_{a}$ の周囲環境を基淮としたエンタルピーの増分で ある.

式(14)〜(16)は, 室内火災で観測される二層環境にも適用可能で ある. 下層（低温層）と上層 (煙層) のそれぞれが一様であると 仮定すると, 式(16)の右辺は下層中 $\left(z<z_{i}\right)$ と上層中 $\left(z_{i}<z\right)$ で はそれぞれゼロであるが，下層から上層に移る境界 $\left(z=z_{i}\right)$ で有 限の値をもつ.

下層中 $\left(z<z_{i}\right)$ では, 式(14) (16)に対して, Morton, Taylor and Turner’が示した解析解をそのまま適用できる. 上層 (煙層) 中 $\left(z_{i}<z\right)$ においては, “境界 $\left(z=z_{i}\right)$ におおける体積流量, 運動量流
束をそれぞれ連続とし，エネルギー流束が式(16)の右辺にしたが つて変化すると仮定すれば, 数值解を求めることができる.

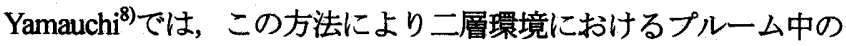
流速分布および温度分布を求めた.この方法によれば, Evans ${ }^{9}$ が 示した実験値に対して十分な精度を持つ解を求めることができる

(Yamauchi $\left.{ }^{8}\right)$ ). しかしながら, 煙層高さ $\left(z_{i}\right)$ や平均温度 $\left(T_{u}\right)$ は 時々刻々変化するため時間ステップごとに式(14)〜(16)の積分を 実行する必要がある点が，工学的に簡便なツールを提供するとい う目的にそぐわない.

熱感知器の作動予測を行うためには，天井付近の感知器が置か れた場所における温度と流速を精度よく近似する必要がある.こ こで紹介するのは, Yamauchi ${ }^{8}$ の方法を簡素化したものである.

Fig. 3 に，二層環境中の境界付近におけるプルームの接続条件を 図示した.

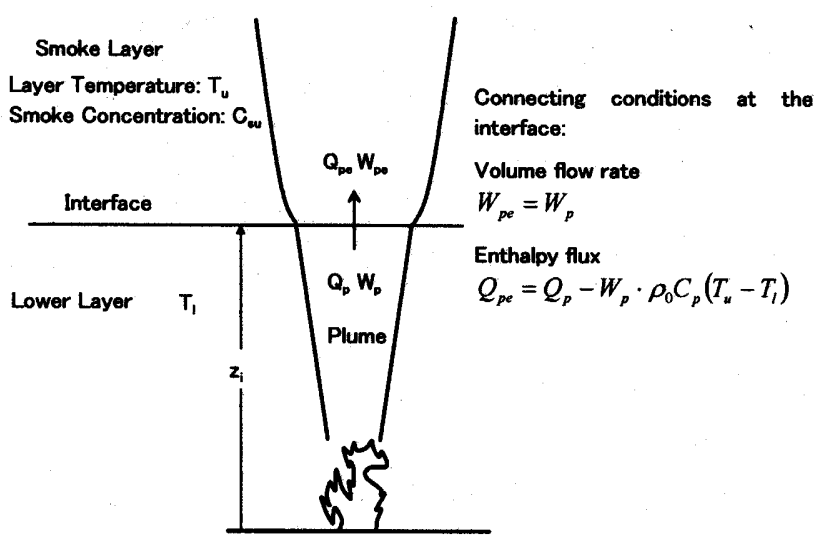

Fig. 3 Connecting conditions of the conserved quantities of plume at the interface of upper and lower layers.

Fig. 3 の条件は，二層の境界にお゙いてプルームの体積流量が連 続であり，エネルギー流束が式(16)にしたがって変化することを 示している. 上層に入ると浮力が小さくなって運動量流束が過剩 となり, 結果的にプルーム幅 $b$ が大きくなって流量 $W_{p}$ の連続性 が保たれる.この過渡的な過程を無視すると，上層におけるプル 一ムの流れは, 温度 $T_{u}$ の一様な仮想空間において境界面の高さ $z_{i}$ で同じ体積流量 $W_{p e}\left(=W_{p}\right)$ を与える等価的な点火源 $Q_{p e}$ により近 似することができる. 等価的な火源の発熱速度 $Q_{p e}$ は元の発熱速 度 $Q_{p}$ よりも小さいので, $z_{i}$ で同じ体積流量を得るためには, 相対 的な火源位置を調節する必要がある. 具体的には, 仮想火源から 天井までの高さ $H_{e}$ を式(2)にしたがって調節すればよい.式(2)は, プルームの運動方程式 (式(14) (16)) の一様な環境に対する解析 解 (式(17)）加導き出される.

$W_{p}=\pi \frac{6}{5} \alpha\left(\frac{9}{5} F \alpha\right)^{1 / 3} H^{5 / 3}$

ここに,

$F=\frac{Q_{p} g\left(\lambda^{2}+1\right)}{\pi \rho_{0} C_{P} T_{0}}$ 
Fig. 4 は，式(1)，(2)（近似計算法）により求めた等価発熱速度 $Q_{p e}$ および等価天井高さ $H_{e}$ を McCaffrey ${ }^{10)}$ の実験式 (式(19)）に代 入して求めたプルーム軸上の上昇温度と Evans ${ }^{9}$ の実験データを 比較したものである. 数值積分により求めた解 (Yamauchi ${ }^{8}{ }^{8}$ ) も 併せて示されている，図を見て分かるように，近似計算法による 上昇温度の予測値は，数値積分による予測值とほぼ一致し，実験 值ともよく合う結果を示した．なお，この計算法では上層と下層 の境界付近で上層温度が不連続となるが，その影響はわずかな範 囲にとどまるので，天井流の予測に実質的な影響を与える恐れは ない.ここに, 計算に用いた MoCaffrey ${ }^{10)}$ の実験式は以下のとおり である.

$\Delta T / T_{0}=21.6 / T_{0} \cdot z^{-5 / 3} Q^{2 / 3}, \quad\left(z / Q^{2 / 5}>0.2\right)$

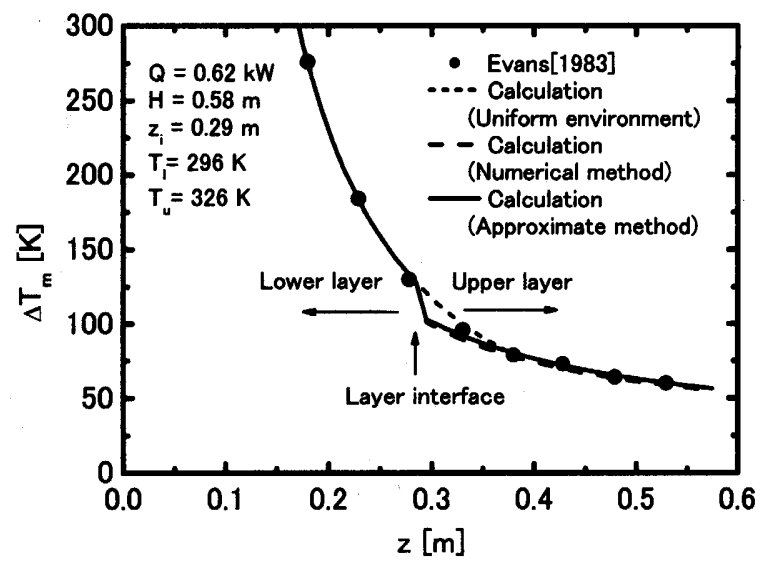

Fig. 4 Calculation results for the plume centerline temperature distribution in a two-layer environment compared with Evans's bench-scale experimental data ${ }^{9}$. The numerical method refers to the method described in Yamauchil ${ }^{8)}$, and the approximate method refers to the method recommended in this study.

二層環境中のプルームの挙動を近似するための工学的な手法は, ほかに Evans"), Cooper ${ }^{11)}$, Watanabe et al. ${ }^{12)}$ から提案されているが, それぞれ目的と手順を異にする. 例えば，三つの方法のうち流速 分布に対する上層の影響を含めてモデル化しているのは Cooper ${ }^{11)}$ だけであり, Evans' と Watanabe et al. ${ }^{12)}$ の方法においては, 上層 中の流速分布が層の存在を受けないことが仮定されている.また， Cooper $^{11)}$ の方法は, 上層の温度によりプルームの突入流量を変化 させる必要があり，そのぶん計算手順が複雑である. 本報で提案 する方法は，計算手順が単純で精度が高い点が特長である.

\section{3 二㾍環境中における天井流の近似}

天井流 (Ceiling-jet) モデルの多くは発熱速度 $Q$ と火源から天井 までの高さ $H$ をパラメータとして, 天井流中の流速 $v$ と上昇温度 $\Delta T$ を求めるようになっている.これらの予測モデルに, 前節で説 明した等価発熱速度 $Q_{p e}$ およひ等価天井高さ $H_{e}$ を代入すると, 上 層の環境中に置かれた天井流中の上昇温度 $\Delta T$ と流速 $v$ を求めるこ とができる. 計算で得られる $\Delta T$ は上層の温度 $T_{u}$ に対する上昇温 度であるので，絶対值はこれに $T_{u}$ を加算して求める.
山内, 万本 ${ }^{13)}$ は，天井流中の上昇温度および流速の水平方向分

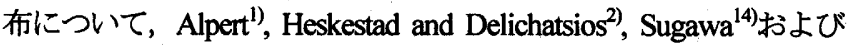
Yamauchi $^{8}$ の各モデルによる予測結果を比較したが，モデル間の 差異は小さく, 二層環境中の天井流の予測において予測值に大き な違いが出る恐れはないとしている。本報では, Heskestad and Delichatsios ${ }^{2}$ の関係式 (式(19),(20)）を使った結果を示す.

$\Delta T^{*}=(0.188+0.313 \cdot r / H)^{-4 / 3}$

$v^{*}=0.59 \cdot\left(\Delta T^{*}\right)^{1 / 2} \cdot(r / H)^{-0.63}, \quad r / H \geq 0.3$

ここに,

$\Delta T^{*}=\frac{\Delta T}{T_{a}} Q^{*(-2 / 3)}$

$v^{*}=\frac{v}{\sqrt{g H}} Q^{*(-1 / 3)}$

$Q^{*}=Q /\left(\rho_{0} C_{p} T_{0} \sqrt{g H} H^{2}\right)$

\section{3. 熱感知器の応答特性と出力変化の予測}

\section{1 熱気流と感熱部の温度変化}

Heskestad and Billにによれば，熱気流中に置かれたスプリンクラ 一感熱部の温度変化は以下の式で表される (Fig. 5 参照).

$\frac{\mathrm{d} T_{s}}{\mathrm{~d} t}=\frac{v^{1 / 2}}{R T I_{s}}\left(T_{g}-T_{s}\right)-C^{\prime}\left(T_{s}-T_{b}\right)$

式(24)において， $T_{s}$ は感熱部の温度, $T_{b}$ はプリンクラーヘッドが 接続された配管部の温度をそれぞれ示す，スプリンクラーヘッド の応答を考える場合には $T_{b}$ を一定と見なすのが一般的である.し かしながら, $T_{s}$ と $T_{b}$ をそれぞれ熱感知器の感熱部と本体と考えて 応答予測に応用しようとすると, $T_{b}$ が短時間で変化するので誤差 の要因となる. すなわち，RTI-C モデルを熱感知器の応答予測に 応用する場合には， $T_{b}$ の時間変化を考慮する必要がある. 具体的 には $T_{b}$ に対して別の $R T I_{b}$ を設定し，その変化を併せて予測する のがよい

$\frac{\mathrm{d} T_{b}}{\mathrm{~d} t}=\frac{v^{1 / 2}}{R T I_{b}}\left(T_{g}-T_{b}\right)$

実際の計算では, 式(24), (25)を以下の表現に変換して使うのが便 利である.

$$
\begin{aligned}
& \frac{\mathrm{d} \Delta T_{s}}{\mathrm{~d} t}=\frac{v^{1 / 2}}{R T I_{s}}\left[\left(\Delta T_{g}+C / v^{1 / 2} \Delta T_{b}\right)-\left(1+C / v^{1 / 2}\right) \Delta T_{s}\right] \\
& \frac{\mathrm{d} \Delta T_{b}}{\mathrm{~d} t}=\frac{v^{1 / 2}}{R T I_{b}}\left(\Delta T_{g}-\Delta T_{b}\right)
\end{aligned}
$$

式の変換にあたって, 
$T_{g}=T_{0}+\Delta T_{g}, T_{s}=T_{0}+\Delta T_{s}, T_{b}=T_{0}+\Delta T_{b}, C^{\prime}=R / R T I_{s}$, の関係を用いた。

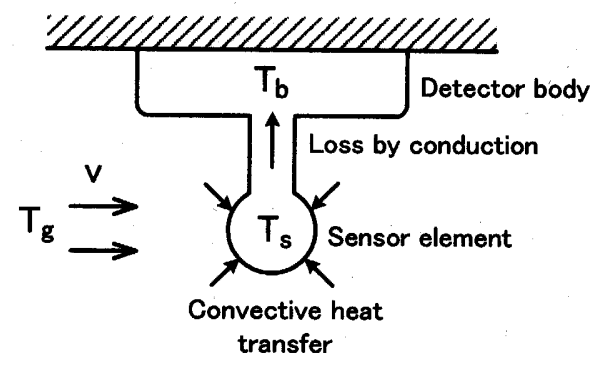

Fig. 5 A schematic of RTI-C model.

Fig. 6 は，熱感知器感熱部の温度変化について，実験値と予測 值を比較したものである. 実験は，流速を一定 $(1.0 \mathrm{~m} / \mathrm{s})$ に保っ た風洞 (UL-521 ${ }^{15)}$ で規定されたもの)の中で，気流温度を一定の上 昇率 $(3.0 \mathrm{C} / \mathrm{min})$ で上昇させて行った. 感知器は, サーミスタを 感熱素子に用いた定温式のものである．使用した熱感知器の応答 特性は, 次節の Table 1 に示されている. 感知器を風洞の中に置き, 安定するまで一定時間待った後，気流温度の上昇を開始させた.

Fig. 6 を見て分かるように, 感知器本体の温度を一定と見なす 1-RTI モデルでは，予測值が常に実測值を下回る結果となる。一 方, 感知器本体の温度を併せて予測する 2-RTI モデルの場合には, 実測値と予測値がほぼ完全に一致している。

作動時間の判定は, 定温式熱感知器の場合, 感熱部温度 $T_{s}$ の予

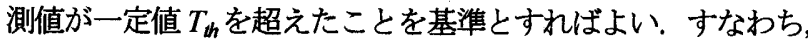

定温式熱感知器の作動条件 : $T_{t h} \leq T_{s}$

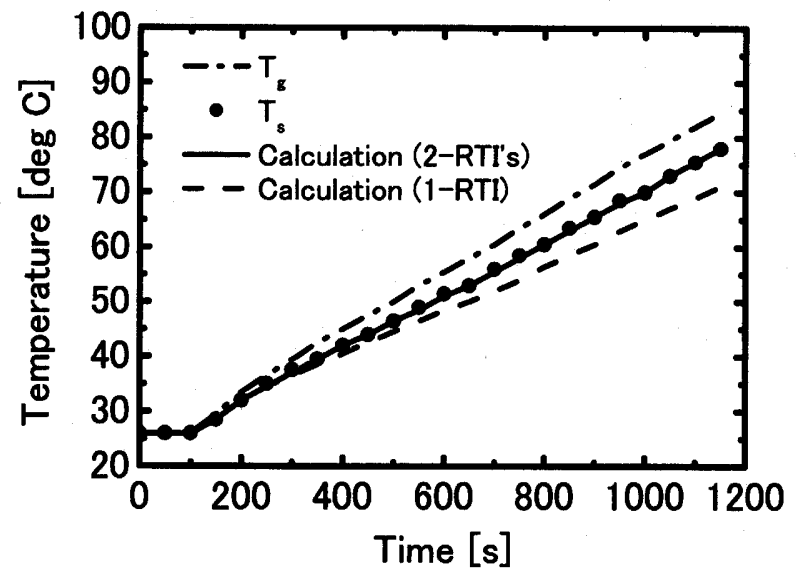

Fig. 6 Temperature variation of the sensing element of heat detector compared with simulated temperatures by 1-RTI and 2-RTI models respectively.

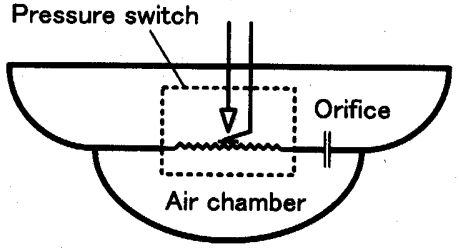

Fig. 7 A schematic of the pneumatic type rate-of-rise detector.

\section{2 差動式感知器の応答予測}

Fig. 7 は, 空気の圧力変化を利用して火災を感知する空気膨張 式の差動式熱感知器の模式図である. 小さなオリフィスを持つ空 気室と空気室内の圧力上昇を検知する圧力スイッチになどにより 構成される. 周囲温度が緩やかに変化する通常の環境では，オリ フィスを通して空気が出入りするため，外気との圧力差はゼロ付 近に保たれる. 火災により感知器が高温にさらされると, 空気室 内の空気が膨張し，一部の空気はオリフィスから外に逃げるが， 同時に圧力が上昇する. 外気との圧力差が一定值を超えると圧力 スイッチが作動し，接点が閉じられる.この過程における空気室 内のエネルギー保存は，以下の式により表すことができる.

$\left(\frac{C_{V} V}{R}\right) \frac{\mathrm{d} \Delta P}{\mathrm{~d} t}+m_{e} C_{p} T=q(t)$

式(28)は，空気室内の空気が吸収した熱量 $(q(t))$ の一部が空気 室内の圧力上昇に使われる一方, 他の部分はオリフィスがら流出 する空気と一緒に外に持ち出されることを意味する. さらに, $\Delta T_{s}$ と $\Delta T_{P}$ をそれぞれ次のように定義すると，

$\Delta T_{P} \equiv \Delta P \cdot\left(C_{V} /(\rho \cdot R)\right), \mathrm{d} \Delta T_{s} / \mathrm{d} t \equiv q(t) /\left(\rho \cdot C_{V} V\right)$

式(28)は以下のように書き換えることができる.

$\frac{\mathrm{d}\left(\Delta T_{s}-\Delta T_{P}\right)}{\mathrm{d} t}=\frac{1}{\tau} \Delta T_{P}$

式(29)において, $\Delta T_{s}$ は空気室内の実際の上昇温度, $\Delta T_{P}$ は空気室 内の圧力上昇を等価的な上昇温度に置き換えて表現したものであ る. $\tau$ は時間の次元を持つ応答指数で，空気室の体積とオリフィ スの流量抵抗などにより変わる.ては設計值であり，感知器のモ デルごとに固有の値となると考えてよい，式(29)は，サ一ミスタ （温度センサ）と微分回路より構成されるサーミスタ式の差動式 熱感知器にも適用可能である. この場合, $て$ は微分回路の時定数 に相当する.

作動時間の判定は, 等価上昇温度の $\Delta T_{P}$ の予測值が一定值 $\Delta T_{t h}$ を超えたことを基準とすればよい.すなわち，

差動式熱感知器の作動条件 : $\Delta T_{t h} \leq \Delta T_{P}$

\section{4. 実験による予測手法の検証}

以上に説明した計算手法の有効性を検証するため，ISO 基淮に よる火災感知器の試験火災 (ISO catalog for full scale fires for smoke and fire detectors ${ }^{16)}$ ) にしたがって実験を実施した，実験室の大き さ, 形状および感知器の設置位置, 燃焼材等の条件は, 全て基準 に規定されたとおりとした．実験では感知器付近の温度変化およ 
び流速の変化を測定するとともに, 感知器の作動時間を観測し, 同条件で行った計算の結果と比較した.

\section{1 宾験の概要}

Fig. 8 は実験室と測定機器の配置を示す. 実験室は $10 \mathrm{~m} \times 6 \mathrm{~m}$ の広さで天井高さは $4 \mathrm{~m}$ である. 火源は部屋の中央の床面に配置 し, 感知器は火源の直上から水平距離 $3 \mathrm{~m}$ の天井面に配置した. 室内の温度分布を測定するため, 天井面付近の水平方向と火源軸 から $4 \mathrm{~m}$ 離れた場所の鈶直方向に熱電対ツリーを配置した.また， 感知器付近に応答性のよい熱電対をぺアで配置し, Motevalli et al. ${ }^{17)}$ の方法を用いて流速を測定した。対流熱伝達による要素だけ を評価するため, 感知器が火炎輻射の影響を直接受けないよう, 遮蔽板を火源と感知器間の気流を妨げない位置に設置した.

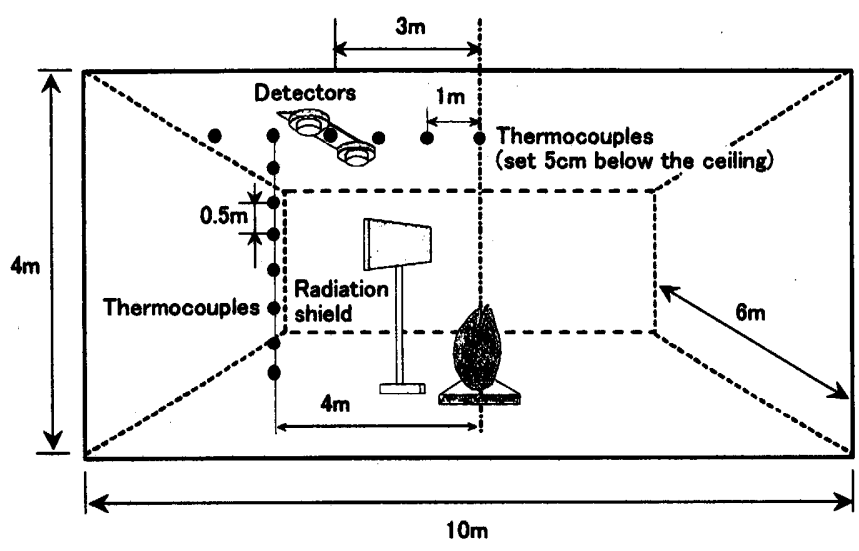

Fig. 8 Experimental room and instruments setup.

\section{2 熱感知器の応答予測結果}

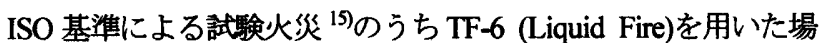
合の実験結果を示す．これはエタノール $(2 \mathrm{~kg})$ を面積 $0.2 \mathrm{~m}^{2}$ の 正方形火皿で燃焼させるものである. 設置した感知器は, 温度セ ンサにサーミスタを用いた定温式感知器 (サーミスタ式), 温度セ ンサにバイメタルを用いた定温式感知器 (バイメタル式), 空気膨 張式の差動式感知器の三種類である. 火源の発熱速度は, 燃焼材 の重量减少速度により求め，計算に使用した，実験に使用した感 知器の応答特性については, 別途に風洞を用いて測定した. Table 1 は, 実験に用いた感知器の応答特性值をまとめたものであ る. 試験火災による実験データと前節で述べた計算手法により予 測した結果を比較した. なお，ゾーンモデルの計算および天井流 の計算において，火源発熱量の $25 \%$ 輻射により失われるものと 仮定した $\left(Q_{p}=0.75 Q_{f}\right)$. これはエタノール火炎に対する文献 值 ${ }^{18)}$ である.

Fig. 9 は，火源から水平距離 $4 \mathrm{~m}$ の位置において，鈶直方向に 設置された熱電対ツリーにより測定された温度の変化と，ゾーン モデルによる計算で求めた煙層温度 $\left(T_{u}\right)$ の時間変化を併せて示 したものである. 図を見て分かるように, $T_{u}$ の計算值は, 高さ 2.5 $\mathrm{m}$ の位置で測定された温度変化とほぼ同様の傾向を示している. この高さは天井流から十分はなれており，天井流の周囲温度の代 表值として妥当なものであると考えられる.

Fig. 10 は，鉛直方向に設置された各熱電対の出力変化と初期温
度の交点を外挿して煙層がその高さに達した時間を求め, 計算值 と比較したものである．実測值と計算值はほぼ一致しており，ゾ ーンモデルによる煙層の予測は妥当なものであると考えてよい.

Table 1 Response characteristics of the heat detector used in the

\begin{tabular}{|c|c|c|c|c|}
\hline $\begin{array}{c}\text { Detector } \\
\text { type } \\
\text { (sensor) }\end{array}$ & $\begin{array}{c}R T I_{\mathrm{s}} \\
{\left[\mathrm{m}^{1 / 2} \mathrm{~s}^{1 / 2}\right]}\end{array}$ & $\begin{array}{c}\mathrm{C} \\
{\left[\mathrm{m}^{1 / 2} \mathrm{~s}^{-1 / 2}\right]}\end{array}$ & $\begin{array}{c}R T l_{b} \\
{\left[\mathrm{~m}^{1 / 2} \mathrm{~s}^{1 / 2}\right]}\end{array}$ & $\begin{array}{c}\text { Threshold } \\
{[\mathrm{C}]}\end{array}$ \\
\hline $\begin{array}{c}\text { Fixed } \\
\text { temperature } \\
\text { (thermistor) }\end{array}$ & 15 & 0.2 & 1000 & $70\left(T_{\text {th }}\right)$ \\
\hline $\begin{array}{c}\text { Fixed } \\
\text { temperature } \\
\text { (bimetal) }\end{array}$ & 15 & 0.2 & 1000 & $60\left(T_{\text {th }}\right)$ \\
\hline $\begin{array}{c}\text { Rate-of-rise } \\
\text { (pneumatic) }\end{array}$ & 15 & 0.2 & 1000 & $15\left(\Delta T_{\text {th }}\right)$ \\
\hline
\end{tabular}

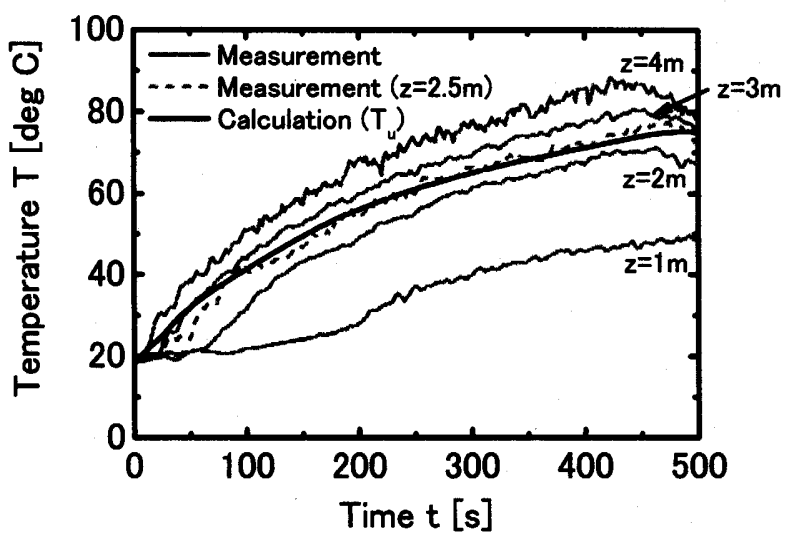

Fig. 9 Observed variations of temperatures measured with a thermocouple tree placed $4 \mathrm{~m}$ from the fire axis, compared with the calculated upper layer temperature with a zone model.

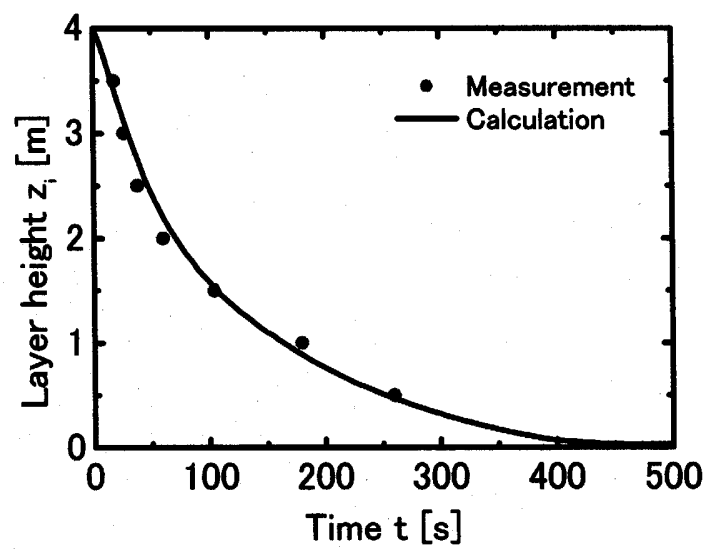

Fig. 10 Observed variation of the layer height compared with calculation. 
Fig. 11 は, 各時刻における等価発熱速度 $Q_{p e}$ および等価天井高 さ $H_{e}$ (式(1),(2)）を Heskestad and Delichatsios ${ }^{2}$ の関係式（式(19)） に代入して求めた天井流中の温度を $1 \mathrm{~m}$ 毎にプロットし, 実験值 と比較したものである. 火源軸の近傍 $(\mathrm{r}=1 \mathrm{~m})$ の位置で若干の 相違が見られるが，総体的な傾向は良く一致している. 火源は $Q_{f}$ が $120 \mathrm{~kW}$ の程度の定常火源であり, 無限天井の場合の感知器近 傍（r=3 m) の上昇温度は室温（約 $20 \mathrm{C}$ ) からせいぜい $20 \mathrm{~K} の$ 程度（約 $40 \mathrm{C}$ ) であるが, このケースでは室温から $60 \mathrm{~K}$ 高い温

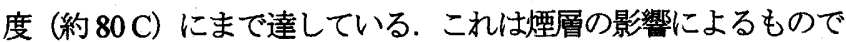
あり，予測値はその影響を精度よく再現している．Fig. 12 は，感 知器近傍 $(\mathrm{r}=3 \mathrm{~m})$ の位置における流速の測定值と式(20)による 予測値を比較したものである．流速の測定值は，気流の摇らぎの 影響を受けて大きくふらついているが，予測值はその平均值に近 い值を示している.

Fig.13 は, サーミスタ式の定温式熱感知器の出力值の時間変化 について，実測值と予測值を比較したものである．気流温度と流 速が精度よく再現されているので，センサ出力の再現性も非常に よい.

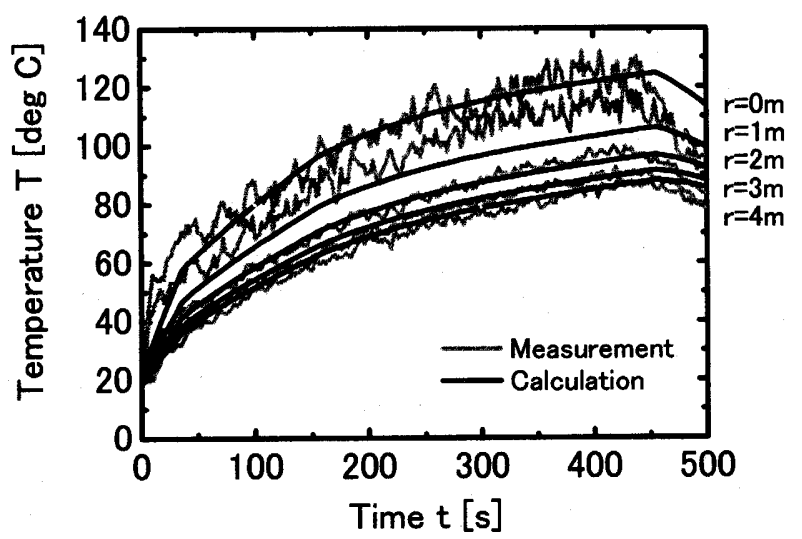

Fig. 11 Comparison of the measured and calculated ceiling-jet temperatures at several radial positions.

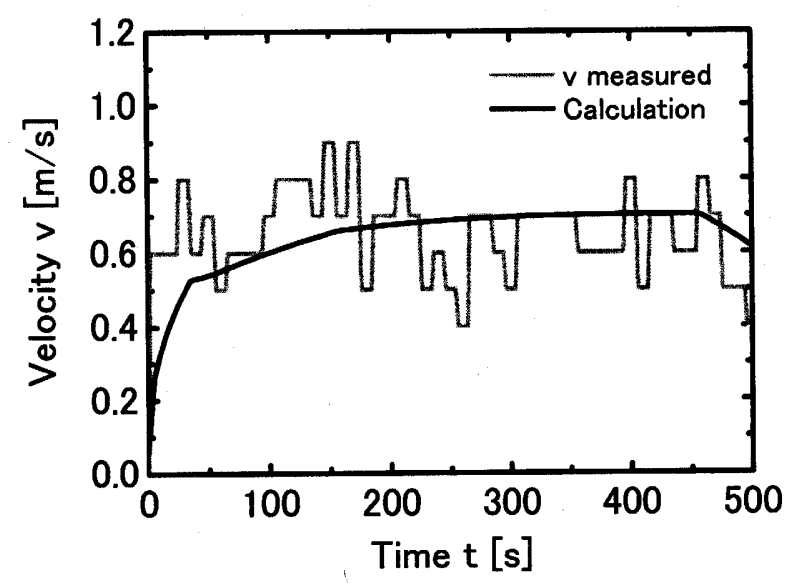

Fig. 12 Comparison of the measured and calculated air velocities at a position near the detector $(\mathrm{r}=3 \mathrm{~m})$.

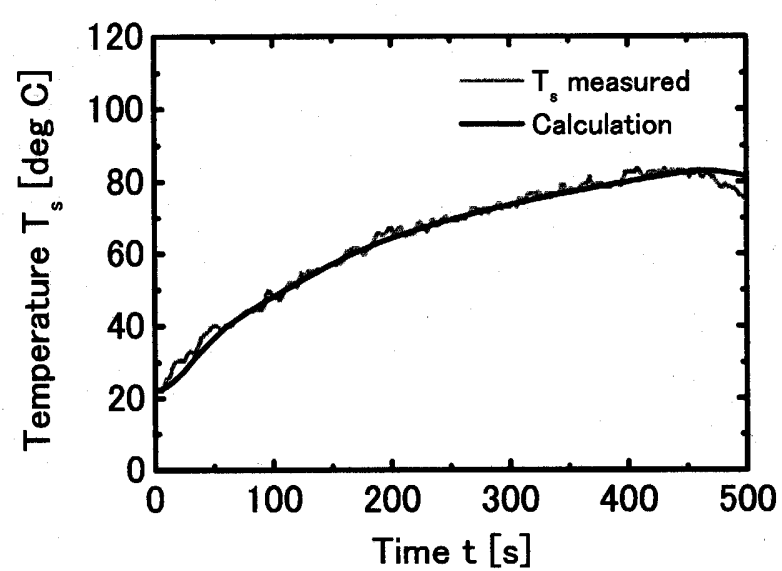

Fig. 13 A result of 2-RTI calculation in the sensor temperature, compared with the observed sensor output variation.

Table 3 は，実験に使用した三種類の感知器について，作動時間の 実測值と予測值を比較したものである. 定温式，差動式ともにサ 一ミスタ式の実測値と予測値の一致は極めてよい，バイメタル式 の定温式感知器においても, 実測值と予測值の差は $20 \mathrm{~s}$ 程度であ る. 実験の再現性を考慮すれば，十分実用に耐える精度である.

Table 3 Comparison of experimental response time with estimation

\begin{tabular}{|c|c|c|c|}
\hline $\begin{array}{c}\text { Detector type } \\
\text { (sensor) }\end{array}$ & $\begin{array}{c}\text { Observed } \\
\text { response } \\
\text { time [s] }\end{array}$ & $\begin{array}{c}\text { Estimated } \\
\text { response } \\
\text { time [s] }\end{array}$ & $\begin{array}{c}\text { Difference } \\
\text { [s] }\end{array}$ \\
\hline $\begin{array}{c}\text { Fixed } \\
\text { temperature } \\
\text { (thermistor) }\end{array}$ & 252 & 260 & +8 \\
\hline $\begin{array}{c}\text { Fixed } \\
\text { temperature } \\
\text { (bimetal) }\end{array}$ & 198 & 170 & -18 \\
\hline $\begin{array}{c}\text { Rate-of-rise } \\
\text { (pneumatic) }\end{array}$ & 48 & 55 & +7 \\
\hline
\end{tabular}

\section{5. おわりに}

室内に設置された熱感知器の作動時間を予測するための工学的 ツールを提供する目的で，簡易的な計算手法を開発した. ゾーン モデルと天井流モデルの組み合わせは，室内火災にお゙いて観測さ れる二層環境中において天井付近の上昇温度と気流速の予測に役 立つことが分かった。

感知器の感熱部と本体に対して二つの異なる RTI を用いる修正 RTI-C モデルは，オリジナルの RTI-C モデルに比べて良好な予測 性能を示した. また, 新たに開発した差動式熱感知器の予測を行 うための計算モデルの予測性能も良好であった. この計算モデル は, 空気膨張式の差動式感知器と温度センサと微分回路よりなる サーミスタ式の差動式感知器のどちらにも適用することができる. 検証実験はまだ十分なものではなく，火源発熱速度や大きさの 
異なる部屋での実験により，適用範囲を明らかにする必要がある. なお，本報で提案したような火災感知時間の予測手法を建物の 安全性評価に適用するためには，まだいくつかの課題が残されて いる. そのひとつは, 火災感知器が具体的に何の目的で設置され ているかということを安全性能の評価基準（クライテリア）とし て明確にすることである. 自動火災報知設備の基本機能は「火災 を（自動的に）見つけて，(人に）知らせる」ことであるが，知ら された人が取る行動一例えば, 初期消火をするのか, 直ちに避難 するのか, 現場確認をしてから避蜼指示を出すのか等にによって, 基淮となる考え方は大きく変わる. すなわち, 評価基準の構築に あたっては, 延焼拡大防止, 避難安全等の各分野における安全性 評価の考え方との整合を図っていく必要がある.

変数表記
$A$
$a$
$b$
$C$
$C p$
$C P$
$g$
$H$
$h$
$l$
$m$
$\Delta P$
$q$

$Q$
$r$
$R T I$
$T$
$\Delta T$
$u$
$v$
$V$
$W$
$x$
$z$

\section{Greek letters}

$\alpha$
$\rho$
$\lambda$
$\lambda_{c}$
$\tau$

$\mathrm{S}$
0
$\mathrm{a}$

Subscripts

c

e

g

i

1

$\mathrm{p}$

R wall surface area facing the smoke layer $\left[\mathrm{m}^{2}\right]$ thermal diffisivity $\left[\mathrm{m}^{2} \mathrm{~s}^{-1}\right]$

$1 / \mathrm{e}$ width of plume [-]

Conductive parameter in RTI-C model $\left[\mathrm{m}^{1 / 2} \mathrm{~s}^{-1 / 2}\right]$

specific heat (constant pressure) $\left[\mathrm{kJ} \mathrm{kg}^{-1} \mathrm{~K}^{-1}\right]$ specific heat (constant volume) $\left[\mathrm{kJ} \mathrm{kg}^{-1} \mathrm{~K}^{-1}\right]$ gravitational acceleration $\left[\mathrm{m} / \mathrm{s}^{2}\right]$

ceiling-height [m]

coefficient of convective heat transfer []

wall thickness [m]

mass flow rate $\left[\mathrm{kg} \mathrm{s}^{-1}\right]$

pressure rise from ambient $[\mathrm{Pa}]$

rate of heat gained or lost by convective heat transfer [kW]

heat release rate $[\mathrm{kW}]$

radial distance from fire axis [m]

Response Time Index $\left[\mathrm{m}^{1 / 2} \mathrm{~s}^{1 / 2}\right]$

absolute temperature [K]

temperature difference from ambient $[\mathrm{C}]$

vertical velocity of plume $[\mathrm{m} / \mathrm{s}]$

radial velocity of ceiling-jet $[\mathrm{m} / \mathrm{s}]$

volume $\left[\mathrm{m}^{3}\right]$

volumetric flow rate $\left[\mathrm{m}^{3} / \mathrm{s}\right]$

distance from wall surface $[\mathrm{m}]$

vertical coordinate $[\mathrm{m}]$

plume entrainment constant [-]

density $\left[\mathrm{kg} / \mathrm{m}^{3}\right]$

Gaussian width ratio [-]

conductivity $\left[\mathrm{kW} \mathrm{m}^{-1} \mathrm{~K}^{-1}\right]$

characteristic response time of rate-of-rise heat detector [s]

initial value

ambient

detector body

convection, conduction

equivalent, exit

fire source, flame

gas

interface

lower layer

plume

pressure

radiation

sensor upper layer

wall

\section{参考文献}

1) Alpert, R. L., Calculation of Response Time of Ceiling-Mounted Fire Detectors, Fire Technology, Vol. 8, pp. 181-195, 1972.

2) Heskestad, G, and Delichatsios, M. A., The Initial Convective Flow in Fire, 17th Symposium (International) on Combustion, The Combustion Institute, Pittsburg, Pennsylvania, pp. 1113-1123, 1978.

3) Heskestad, G, and Bill, R. 'G Jr., Modeling of Thermal Responsiveness of Automatic Sprinklers, Proceedings of the Second International Symposium for Fire Safety Science, pp. 603-612, 1989

4) Tanaka, T. and Yamada, S., BRI2002: Two Layer Zone Smoke Transport Model, International Journal for Fire Science and Technology, Vol. 23, special issue, 2004.

5) Peacock, R. D., Fomey, G. P., Reneke, P. A., Porter, R. M. and Jones, W. W., CFAST, the Consolidated Model of Fire and Smoke Transport, National Institute of Standard and Technology, NIST TN 1299, 1993.

6) Zukoski, E. E., and Kubota, T., Two Layer Modeling of Smoke Movement in Building Fires, Fire and Materials, Vol.4, No.1, 1980.

7) Morton, B. R., Taylor, G, and Tumer, J. S., Turbulent Gravitational Convection from Maintained and Instantaneous Sources, Proc. Roy. Soc. Lond. A., Vol. 234, January 1956.

8) Yamauchi, Y., Prediction of Response Time of Smoke Detectors in Enclosure Fires, National Bureau of Standards (U.S.A.), NBSIR 88-3707, January 1988.

9) Evans, D. D., Calculating Fire Plume Characteristics in a Two Layer Environment, National Bureau of Standards (U.S.A.), NBSIR 83- 2670, September 1983.

10) McCaffrey, B. J., Purely Buoyant Diffusion Flames: Some Experimental Results, National Bureau of Standards (U.S.A.), NBSIR 79-1910, October 1979.

11) Cooper, L. Y., A Buoyant Source in the Lower of Two, Homogeneous, Stratified Layers - A Problem of Fire in an Enclosure, The American Society of Mechanical Engineers, ASME Publication 83-WA/FE-4, 1983.

12) Watanabe, J., Shimomura, S., Aoyama, Y., and Tanaka, T., Formula for Prediction of Ceiling Jet Temperature in Two Layer Environment, Proceedings of the Seventh Intemational Symposium for Fire Safety Science, pp. 431-442, 2003.

13) 山内幸雄, 万本敦, 光電式煙感知器の作動時間予測のための 計算手法，日本火災学会論文集，Vol.52, No.2, pp.17-24, 2002.

14) Sugawa, O., Simple Estimation Model on Ceiling Temperature and Velocity of Fire Induced Flow under Ceiling, Fire Science and Technology, Vol. 21, No. 1, pp. 7-67, 2001.

15) Heat Detectors for Fire Protective Signaling Systems-UL-521, Underwriters Laboratories, U.S.A., 1993.

16) ISO Catalog for Full Scale Test Fires for Smoke and Fire Detectors of Fire Detection and Alarm Systems, Draft 7, 1996.

17) Motevalli, V., Marks, C. H., and McCaffrey, B. J., Cross-Correlation Velocimetry for Measurement of Velocity and Temperature Profiles in Low-Speed, Turbulent, Nonisothermal Flows, Transactions of the ASME, Vol. 114, pp. 332-337, May 1992.

18) Tewarson, A, Generation of Heat and Chemical Compounds in Fires, SFPE Handbook of Fire Protection Engineering, Third Edition, National Fire Protection Association (U.S.A.), pp. 3-82-3-161, 2002.

（2005年 5 月 10 日原稿受理， 2006 年 1 月 25 日採用決定） 